\title{
A BIG RESPONSIBILITY!
}

THE MORALISATION OF MARKETS AND THE RISE OF SUPERMARKET PATRIOTISM

\author{
Juan Diego Sanin
}

\begin{abstract}
This article looks at how the 'moralisation of economy' - a phenomenon associated with the neoliberal culture - is manifested in Australia. It argues that a distinctive characteristic of this phenomenon is the adoption of patriotism as the responsibility of producers, ethical concern of consumers and property of commodities. This argument will be advanced through a case study focusing on the branding campaigns of Australia's two biggest supermarket chains, Woolworths and Coles. This study demonstrates how neoliberalism and nationalism are not binary paradigms. In particular, it shows that parallel to the decline of the nation-state there is another process related to the rise of nationalistic corporations; a phenomenon that I propose to call 'supermarket patriotism'. However, far from being a balancing force that alleviates the inequalities of 'extreme capitalism,' this form of patriotic moralisation proves neoliberalism's ability to transform critique into promotion, moral values in commodities and civic action into shopping practices.
\end{abstract}

Keywords: supermarket patriotism, moralisation of markets, Australian supermarkets

\section{INTRODUCTION}

Since the mid-20oos, economic sociologists examining neoliberal culture have observed that parallel to the 'economization of politics' there is another process, something they call the 'moralisation of economy' (Fourcade and Healy, 2007; Shamir, 2008a, 2008b). This perspective suggests that neoliberalism is a twofold process. On the one hand, it is characterised by the adoption of corporate cultures and principles of economic sustainability by all kinds of institutional authorities; the management of public services within markets and as if they were commodities; and the treatment of citizens as consumers. On the 
other hand, emergent characteristics of neoliberalism include the adoption of moral responsibilities by corporations; the consolidation of ethical forms of consumption; and the commoditisation of social, cultural and environmental causes to be advanced in the marketplace.

While issues associated with the economisation of political spheres have been widely explored and mechanisms of privatisation, deregulation and corporatisation are well known, the moralisation of economic spheres and the mechanisms by which moral causes are embedded in the market have remained overlooked. Literature on the moralisation of economic spheres has shown that moral causes and the strategies to advance them vary from one market to another (Shamir 2005). This means that moralisation works differently in every context, which makes it difficult to reach any agreement about what moral values are embedded in commodity markets and how they are advanced by producers and consumers (Stehr and Adolf 2010, 215). It is in examining the moral values embedded in commodity markets that this article aims to make a contribution, revealing some of the key characteristics of the moralisation of the economy in Australia.

Drawing on a case study of Australia's 'big two' supermarkets, Woolworths and Coles, this research demonstrates that one manifestation of the moralisation of the economy in Australia is that patriotism works as a moral responsibility of producers, an ethical concern of consumers, and a property of commodities. This form of moralisation means that patriotism is reflected not only in supermarkets' advertising - as has been common for years - but also in their sourcing policies, ways of doing business, social responsibilities and in-store experience. This case study is part of a broader research on manifestations of commercial nationalism in Australia. The findings discussed in this article are drawn from fieldwork conducted in several supermarkets' stores in Melbourne during 18 months (June 2012 - December 2013). This fieldwork was complemented with a textual analysis of corporate documents, promotional materials and news media coverage of Woolworths' and Coles' branding campaigns.

The article develops its arguments about the moralisation of the economy in two sections. The first reviews general characteristics of this phenomenon, and the second analyses how it is manifested in Australia through the rise of 'supermarket patriotism. The discussion explains how, in their branding campaigns, 'Australia's Fresh Food People' and 'Helping Australia Grow', Woolworths and Coles have adopted a series of national causes as part of their corporate responsibilities; have attributed patriotic properties to food commodities; and transformed their stores into sites where citizens are supposed to participate 
in national development through their shopping decisions.

The findings of the article demonstrate the way in which neoliberalism and nationalism are not necessarily opposed to each other. Seen from the perspective of modern nationalism, the rise of supermarket patriotism suggests that, parallel to the decline in the control exerted by nation-states over national culture associated with neoliberalism, there is another process. This process revolves around the rise of the nationalist corporation, a private organisation that assumes a national agenda that is advanced in the marketplace. I claim that far from being a balancing force alleviating the inequalities of 'extreme capitalism', this surge of 'supermarket patriotism' is part of branding strategies aimed at creating and controlling markets that revolve around nationalistic forms of consumption. This research confirms the view that the moralisation of economy reinforces the neoliberal paradigm rather than diminishing it. It is, in other words, business as usual.

THE MORALISATION OF MARKETS: RESPONSIBLE CORPORATIONS, ETHICAL GOODS AND CITIZEN-CONSUMERS

There are various - and at times almost contradictory - explanations for why the moralisation of economy occurs, and thus there are different ways a discussion about the moralisation of Australian supermarkets could be situated. The most optimistic of these theories see the embedding of moral values in the economy as a form of social empowerment resulting from the increasing levels of wealth among first world capitalist societies, and describe its effects in terms of a redistribution of powers in market relationships between producers and consumers (Marsland 2001; Stehr 2008; Stehr and Adolf 2010). Although this article engages with some of these ideas, theories explaining the moralisation of economy within the context of neoliberal culture will be used extensively. For example, Shamir explains that since the rise of neoliberalism, forms of top-down authority are being replaced by other forms of governance based not on obedience but on 'responsibilisation'. The logic of responsibilisation presupposes the moral agency of organisations, individuals and things (Shamir 2008a, 7). It expects auto-regulation from corporate organisations, entrepreneurial disposition from consumers and ethical performativity from commodities. I will argue that it is as a result of these changes in the forms of authority (and not changes in relations of power), and through the processes of responsibilisation (instead of social empowerment) that culture - in the form of moral values - is embedded in the neoliberal economy. From an empirical perspective the moralisation of economy is evident in the responsibilisation of market actors, more exactly in the moralisation of production, consump- 
tion and commodities. This section builds on critical approaches to consumer culture to explain the general characteristics of this phenomenon. After that, the second part of the article analyses particularities of the moralisation of the economy in Australia.

At the level of production, the moralisation of markets is manifested through the adoption of moral responsibilities by corporations. Shamir explains that commercial organisations are performing tasks and assuming responsibilities that have been traditionally considered as part of 'the civic domain of moral entrepreneurship and the political domain of the caring welfare state'; and consequently, corporations have started to dispense 'social goods other than profits to constituencies other than their share holders' (Shamir 2008a, 2; $2008 \mathrm{~b}, 3)$. The most prominent manifestation of this process is the flourishing of Corporate Social Responsibility and the pervasiveness of reports explaining how corporations are committed to social issues, supposedly beyond their economic interests. But far from being altruistic, Corporate Social Responsibility is increasingly becoming an important element of mainstream business model in neoliberal culture, which according to marketing experts is good for doing business (Trudel and Cotte 2009; Trudel and Gote 2008). Critics of Corporate Social Responsibility (Boje, Khan, and Dawood 2009; Fleming and Jones 2013; Littler 2009 Ch. 3) have shown that these programs are part of branding strategies aimed at managing corporate reputation and controlling new markets around 'responsible' modes of consumption (Fleming and Jones 2013, 12).

In terms of consumption, moralisation occurs through ethical consumerism, a purchasing behaviour peculiar to Western consumer cultures (Humphery 2010) in which consumers are supposed to be 'unselfish' (Peattie 2012) and consider the impact of 'their everyday consumption practices from a moral perspective' (Grazia and Uusitalo 2014). Historically, the most important characteristic of this movement is the belief that shopping decisions have political implications (Gabriel and Lang 2005; Hilton 2003) and that consumers can 'vote with their dollar' (Gabriel and Lang 2006, 175-177). This conviction has created a neoliberal form of consumer-citizenship in which all forms of civic participation became mediated through the marketplace (Banet-Weiser and Lapsansky 2008). Although ethical consumption did emerge in response to the neoliberal politics of Reagan and Thatcher (Gabriel and Lang 2006, 167), these forms of social dissent were rapidly integrated into capitalist systems, commoditised and transformed into 'new' markets. Those ethical markets, however, target wealthy and educated consumers (Johnston, Szabo and Rodney 2011), and participating in them has become a marker of cultural distinction that generates social exclusion (Littler 2011, 34). 
The most visible form of commodity moralisation is the recent explosion of 'ethical goods' (Littler 2009) - commodities to which a moral agency is attributed. Using buzzwords such as 'fair trade,' free range,' 'organic,' sustainable', or 'authentic', the advertisements and packaging of these commodities argue for the products' ability to change the lives of peoples, animals and workers, to fight for social change, stop global warming or prevent AIDS. This phenomenon has created a sort of neoliberal 'commodity activism' (Banet-Weiser and Mukherjee 2012b) or 'brand aid' (Richey and Ponte 2011), in which civic and social causes are advanced though commodity consumption. However, scholars examining consumer culture have warned that the morality of ethical goods is paradoxical. Firstly, 'grafting philanthropy and social action on to merchandising practices, market incentives and corporate profits' is contradictory (Banet-Weiser and Mukherjee 2012a, 1). Secondly, "'ethical" products and services produced by corporations can be indeed of progressive value, but crucially, only at the whims of corporations themselves' and are often used to hide exploitative aspects of their corporate practices (Littler 2011, 32). Overall, the moralisation of economy has transformed the market into a place of commercialised civic action, reinforcing the neoliberal conviction that markets are democratic systems, where corporations work to identify the popular will of 'the people' and to translate it into commodities that allow citizens to vote with their dollar (Frank 2000).

THE RISE OF SUPERMARKET PATRIOTISM

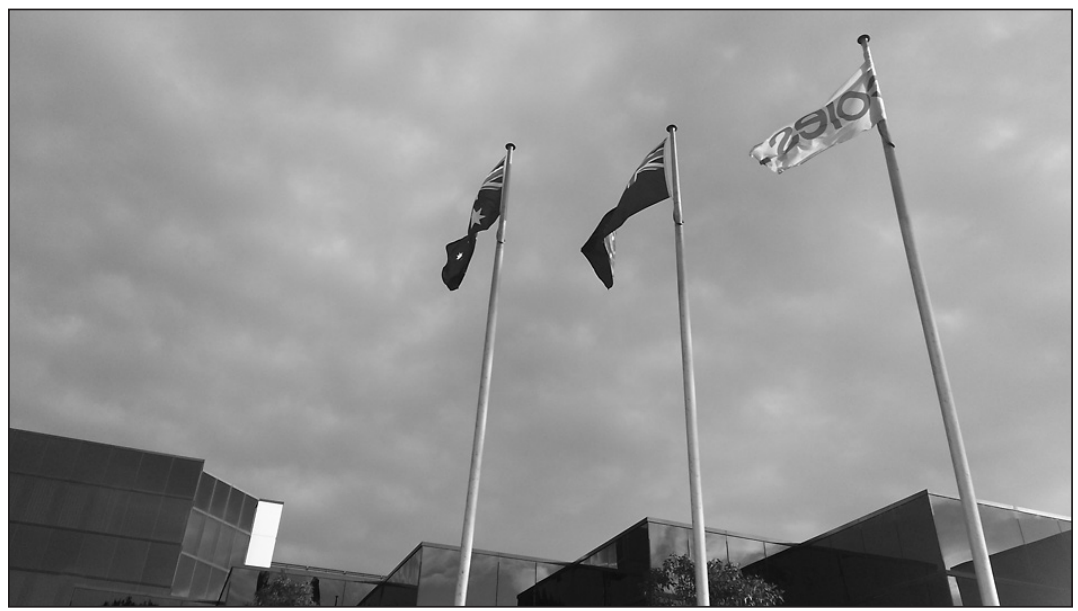

Figure 1. National and corporate flags at Coles' headquarters in Melbourne. 
Reflecting current trends on the study of neoliberal culture, discussions about supermarkets in Australia have revolved around the neoliberal economisation of politics, focusing on the 'supermarket power' that Woolworths and Coles have reached in the last five years and the forms of authority that they exercise across supply chains and markets (Richards, Lawrence, Loong and Burch 2012). Market research shows that Woolworths and Coles control together more than 70 per cent of the Australian retail market and that international chains such as Aldi or independent supermarkets such as IGA have a marginal participation of just around 10 per cent each (Roy Morgan 2014). The moral dimension of this process, however, has not yet been explored. The moralisation of supermarkets is becoming highly visible at an international level though, with big chain retailers incorporating principles of Corporate Social Responsibility into their operations, listening to the demands of ethical consumers and converting their private labels into ethical goods.

Table 1. Market share of supermarkets operating in Australia according to Roy Morgan Research (Roy Morgan 2014).

\begin{tabular}{|l|c|}
\hline Supermarket & Share of market \\
\hline Woolworths & $39.0 \%$ \\
\hline Coles & $33.5 \%$ \\
\hline Aldi & $10.3 \%$ \\
\hline IGA & $9.5 \%$ \\
\hline Other supermarkets & $7.7 \%$ \\
\hline
\end{tabular}

The majority of the responsibilities adopted by supermarkets are detached from national matters and placed within a global context. For example in Britain, the global supermarket chain Tesco has put the community at the heart of what [they] do' (Seth and Randall 2011,35), without emphasising whether it is a British community. Tesco's social responsibilities have a global perspective: to create 'new opportunities for millions of young people around the world'; 'reduce food waste globally'; and 'help to tackle the global obesity crisis' improving the health of colleagues and customers (Tesco 2013, 5). In this way, the supermarket presents itself as committed to global issues.

In Australia and New Zealand, the moralisation of supermarkets is different from Europe and presents patriotic connotations. In both countries, national (e.g. New World Supermarkets in New Zealand) and international (e.g. Aldi) 
supermarket chains adopt national causes as part of their corporate responsibilities, give preference to local suppliers and develop advertising campaigns based on nationalist imagery. The nationalist attitude of supermarkets in Australia and New Zealand is reinforced by buy national campaigns such as 'Australian Made' and 'Buy New Zealand Made'. The country-of-origin logos of these and other campaigns are extensively utilised in supermarkets and their media campaigns depict the act of buying national goods as a responsibility that consumers have with their country. Marketing studies have shown that these campaigns have had a positive response from consumers in both countries (e.g. Fischer and Byron 1997; Insch and Jackson 2014). Nevertheless, as it will be explained later, ethnocentric consumer behaviours are more visible in Australia, where many consumers consider the purchasing of national goods as an ethical obligation toward national development.

The patriotic connotations of the moralisation of the economy are especially evident in Woolworths and Coles. For both supermarkets, patriotism is seen as a corporate responsibility, a demand of consumers and a property of food commodities. This patriotic tone is not fortuitous; it is a strategic response to complaints against Woolworths' and Coles' corporate practices and their impact on the national economy, as well as an attempt to profit from the ethnocentric preferences of consumers.

Firstly, the adoption of patriotism can be understood as a branding strategy developed by supermarkets to protect their reputation from criticisms and investigations against the negative effects of their 'supermarket power' on sectors of national economy. Since 2008, Woolworths and Coles have engaged in a series of competitive practices labelled by the media as the 'supermarket wars. The most prominent example of this conflict was the introduction of disproportionate discounting on foods, presented to customers through suggestive campaigns such as 'Down, Down' in the case of Coles and 'Price Knockdown' (and recently 'More Savings') in the case of Woolworths. Although these schemes may look good for consumers, supermarkets have been accused of misusing their power over retail markets and supply chains to achieve the price discounts, for which their corporate practices have been investigated by the Australian Competition and Consumer Commission (ACCC 2008) and by Senate Inquiries (Commonwealth of Australia 2011; 2012). Coles and Woolworths have been accused of expanding their private labels using imported foods, making dubious contracts with local suppliers, threatening farmers in order to get them to accept exploitative conditions and of driving out small businesses in suburbs and rural areas (e.g. Cowie 2011a, 2011b, 2011c; Dalley 2012a, 2012b; Dalley and Sheftalovich 2012; Fyfe and Millar 2012). 
The adoption of patriotism by Coles and Woolworths is also a strategic response aimed at increasing profits, taking advantage of the nationalistic preferences of Australian shoppers. A study examining the attitudes of Australian consumers towards grocery shopping in relation to ethics found that patriotism was a major factor of decisions made about product and brand choice (Williams et al. 2010). During the supermarket wars, similar findings were reported by market research indicating that 88.5 per cent of consumers preferred Australian-made products (Australian Made 2000; Roy Morgan 2013), and in opinion polls suggesting that shoppers were even willing to pay more for them (Fyfe and Millar 2012). According to the organisation 'Australian Made,' this preference is most prominent in relation to food, and the main reason for doing it is 'to support Australian growers and manufacturers' (Australian Made 2012). The results of that research suggest not only a nationalistic attitude in Australian consumers, but also a growing concern about the corporate practices of supermarkets, and in particular their impact on local farmers, small business and suppliers.

By mid-2012, criticism of Woolworths and Coles' supermarket war was threatening their brand image. In response, both supermarkets released new branding campaigns combining moral responsibilities and patriotism. In these campaigns Coles and Woolworths promised to take their responsibilities as the biggest supermarkets of Australia seriously and to satisfy the nationalistic demands of consumers. In June, Woolworths rebranded its image by changing its 25-year-old slogan 'The Fresh Food People' to 'Australia's Fresh Food People' (AFFP hereafter), as a way to emphasise their commitment to Australia. In October, with a very similar purpose, Coles launched 'Helping Australia Grow' (HAG hereafter). Apart from promising savings and low prices, the campaigns were used to emphasise the fact that each supermarket had a patriotic commitment to Australia.

These campaigns are a clear example of the moralisation of markets, though with a patriotic twist. Supermarkets, as will be shown later, have rendered their socio-moral obligations as a national responsibility and transformed their corporate policies and schemes into patriotic agendas. Moreover, their stores are set up as platforms where citizen-consumers can express their patriotism by advancing different national causes while shopping, and their products promise to help local communities and solve national issues. Overall, the rise of supermarket patriotism represents an atypical form of the moralisation of the markets. While retailers and shoppers around the world are engaging in global causes, in Australia, the socio-moral obligations of supermarkets, ethical concerns of consumers and consequently the moral agency of commodities 
are influenced by patriotism and explained using nationalistic statements. The two following sections explore this phenomenon further.

NOT JUST A BIG BUSINESS! THE SUPERMARKET AS A NATIONAL INSTITUTION

Due to the process of responsibilisation, Australian supermarkets have focused on patriotism and developed initiatives to address criticism of their exploitative practices by focusing on how their corporate operations contribute to solutions on a wide range of national issues. As part of this patriotic turn in the corporate cultures of supermarkets, Woolworths and Coles have built a public image that portrays them not only as responsible corporations, but as institutions committed to the advancement of national causes. It is from this perspective that I propose to think of supermarkets as 'national institutions' in the neoliberal era, or alternatively, as corporations with nationalistic agendas that are advanced in the marketplace.

This section looks at the strategies used by Woolworths and Coles to reinvent themselves as national institutions. Despite the possible impact that these strategies of corporate nationalism could have, I argue that supermarkets' altruistic objectives should not be taken for granted and must be considered as part of branding programs aimed at creating and controlling a market around patriotic consumerism and at encouraging nationalistic preferences in Australian citizen-consumers. Through the campaigns AFFP and HAG, Woolworths and Coles presented themselves not only as businesses trying to make money, but as institutions committed to national causes. As this section will show, this is done through corporate branding, sourcing policies and Corporate Social Responsibility schemes.

As mentioned above, one of the main criticisms of Woolworths and Coles was the irresponsibility of their behaviour in regards to the impact that their corporate practices could have on local farmers and suppliers. Statements released by both supermarkets announcing their patriotic campaigns addressed these criticisms, stating that they were a consequence of misinformation and promising to behave as responsible businesses. Woolworths' Managing Director described how the company does 'have a responsibility as Australia's largest supermarket to better explain to customers where their food comes from, and the media statement claimed that 96 per cent of fresh produce and 100 per cent of meats were Australian grown (Woolworths 2012d). Similarly, Coles used the catchphrase 'We know we are a big business. We know we've got a big responsibility' to present its campaign, and clarified that 96 per cent of their 'fruit and veg' were 'grown right here at home' and that 'buying Australian produce 
generates billions of dollars for the rural economy (Coles 2012C).

The television advertisements launched as part of AFFP and HAG also addressed these criticisms. In particular, both Coles and Woolworths focus on issues relating to their supply chains and the satisfaction of farmers and suppliers working for the respective supermarkets. The stars of Woolworths' advertisement 'Welcome to Australia's Fresh Food People' were 'real people' involved in the different stages of the supermarket's supply chain, including the farmer, the fruit picker, the truck driver and other store personnel. The advertisement focused on the Australian production of the food and suggested that relationships between Woolworths and their suppliers were very good ones. The advertisement 'Helping Australia Grow' showed celebrity chef and Coles' brand ambassador, Curtis Stone, explaining that 96 percent of the fruit and vegetables as well as 100 percent of meats sold at the supermarket were 'Australian grown' and confirmed that it was part of their commitment to help the country. These advertisements demonstrate an interesting shift in supermarket promotion, moving from promising customer satisfaction to the satisfaction of everyone involved in the supply chain.

As part of their corporate nationalism Woolworths and Coles have implemented sourcing policies aimed at giving preference and offering privileged trading terms to local suppliers. These policies are promoted using persuasive names such as 'Australia First' (Coles 2011a) and 'Local Food Sourcing Strategy' (Woolworths 2013b), and are accompanied by programs aimed at finding local substitutes for overseas imported products. These policies have become a key element of Woolworths' and Coles' campaigns, and have been especially useful for brand-washing and avoiding criticism of these supermarkets' private labels, which are now produced using 90 per cent local ingredients. In order to achieve these levels of local sourcing both supermarkets have removed imported products from their shelves (including many from New Zealand (Harper 2014)) and replaced their contracts with suppliers from other countries with local ones. However, the suppliers favoured by these new contracts are not exactly true-blue farmers or small local companies, but the big players of Australia's agroindustry. Woolworths is now sourcing all its home-brand canned fruits from SPC Ardmona (Woolworths 2013c), a subsidiary of CocaCola Amatil; and Coles made a contract with Simplot Australia (Coles 2012a), a subsidiary of the multinational Simplot, for its frozen vegetables.

The patriotic character of the moralisation of supermarkets is also visible in their Corporate Social Responsibility schemes. Although both Coles and Woolworths were running different CSR initiatives before 2012, after their pa- 
triotic turn these programs were redefined as 'Australian' and reinterpreted as patriotic initiatives implemented as part of their agendas for national development. This dimension of the moralisation of supermarkets reflects what some optimistic management scholars call 'Political CSR', a practice in which private companies assume a public role, and 'business firms' get engaged in 'activities that have traditionally been regarded as actual governmental activities' such as health, education, social security, protection of human rights, social ills, protection of the environment and self-regulation (Scherer and Palazzo 2011).

The patriotic tone and political involvement of Woolworths' and Coles' CSR is evident through the programs each chooses to publicise on the micro websites of their campaigns. In the website for AFFP (Woolworths 2012b), there is a section called 'Australia's' that explains Woolworths' programs with a national accent and puts them in a political perspective. 'Woolworths is proud to be Aussie through and through' says the main screen of this section. After that, continuing screens explain how 'Woolies' (as it is affectionately called by the public) is helping 'Young Australians' through programs aimed at providing 'Aussie kids' with educational resources (Earn \& Learn) and a 'better understanding of good nutrition' (Fresh Food Kids), as well as at guaranteeing their health through fundraising (Hospital Appeal) and support to charities. Further, Woolworths presents its programs for improving the 'future of rural Australia' by investing in 'farming innovation, productivity and long term sustainability' (Fresh Food Future) and by supporting the 'next generation of farmers' through education (Agricultural Business Scholarships). The website also explains how the campaign Fresh Food Rescue is helping Australians in need, saving food surplus and transforming this surplus into 'meals for the needy' (Woolworths 2012c). The final section of the website makes clear how Woolworths is employing more than 110,000 'Aussies' from diverse cultural backgrounds 'From Australia to Africa, Asia to Europe, and New Zealand to the Middle East.'

The microsite of HAG (Coles 2012b) has also portrayed Coles CSR programs as patriotic initiatives. For example, the supermarket has renamed its partnerships with charitable organisations as its 'National Charity Support'. The most prominent of these partnerships is the one with 'Red Kite', an initiative to support Australian children with cancer. The launch of this initiative coincided with Australia Day 2013 and Coles presented this campaign as part of their patriotic commitment to Australia. Coles has also developed the program Second Bite which has as its objective to 'assist the estimated 1.2 million Australians who don't have access to a safe, regular, and affordable food supply' by donating surplus food. Another dimension of the 'political' role Coles is seeking to 
play is evident through the campaign labelled 'Local Community Initiatives' which includes supporting Indigenous Australian children under the program 'Boots for Kids', local schools (giving them sport equipment through 'Sports for Schools'), as well as other sectors of Australian population through fundraising and donations. Interestingly, Coles has also developed a patriotic focus when engaging with issues of ethical sourcing and sustainability, presenting animal welfare initiatives (e.g. free range pork, free cage eggs) and environmental programs (e.g. recycling plastic bags) as moral obligations of the company with Australia.

Two years after AFFP and HAG have been released, Woolworths and Coles continue to reinvent themselves as national institutions by integrating patriotism into their corporate cultures. The latest strategy has been the construction of visual stories, where they use statistics to measure the results of their nationalistic agendas. These are not modest. In its 'Grocery Facts' (Woolworths 2013a), Woolworths describes its 111,304 employees, the 2 million meals donated to the hungry, the $\$ 62.3$ million raised for charities, and the $\$ 6.3$ billion paid to employees as part of its contribution to national development. This section also claims Woolworths sells a high percentage of 'Aussie' fruits, vegetables and

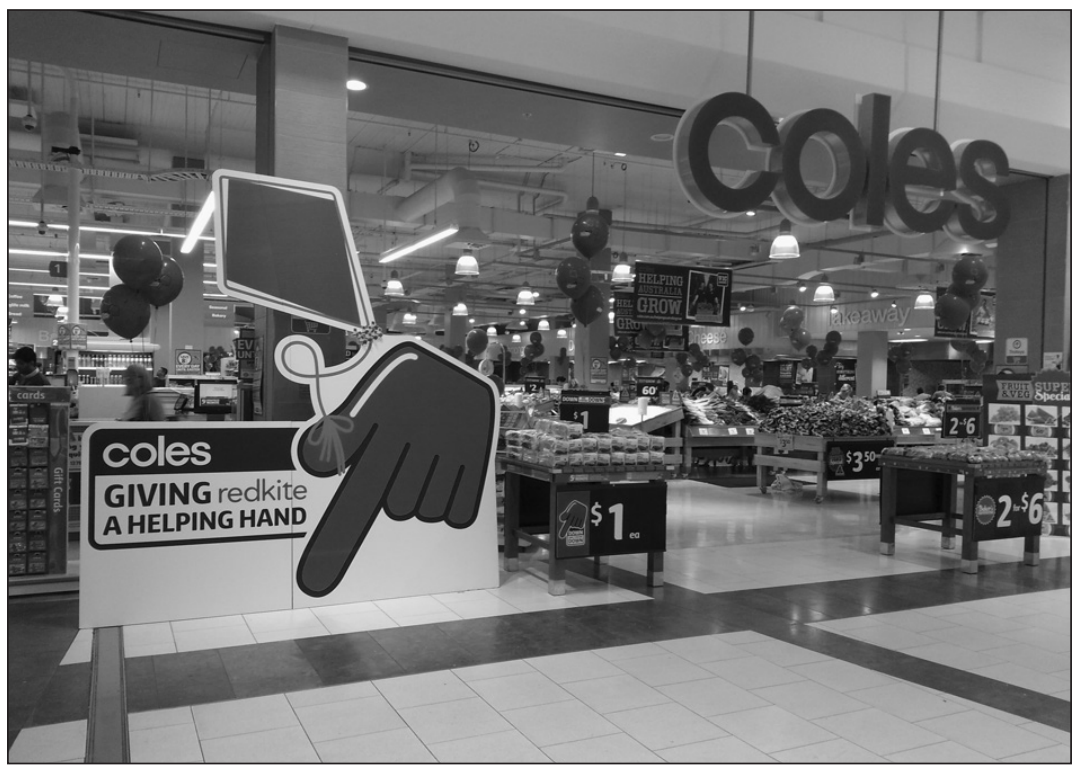

Figure 2. Coles Tooronga on 'Australia Day' 2013. 
meats. Coles is more emphatic in this sense and has created a 'Timeline' (Coles 2013) answering the question: 'How is Coles helping Australia grow?' The story begins in 1982, when it started to support Guide Dogs Australia, and goes until 2015, when it will sell only 'Responsibly Sourced Seafood'. Coles' timeline describes donations of money and food to charities, ethical sourcing policies, educational programs, contracts with Australian suppliers and generation of employment as ways in which the supermarket is 'helping Australia grow'. In 2014 Woolworths and Coles announced more patriotic actions that - according to news media reports - have pleased Australia's Prime Minister Tony Abbott. Early in the year, Woolworths announced another multimillion dollar contract with SPC Ardmona (Bourke 2014), saving the company from bankruptcy; and Coles' Managing Director announced that as part of Coles' 10oth anniversary, it will create 16,000 new jobs across Australia (Maher 2014).

But while it is true that Woolworths and Coles are involved in national issues, the altruistic intentions of their campaigns should not be taken for granted. Many of the problems they claim to fight, such as farmer and supplier dissatisfaction, increases of imported foods or expansion of home brands, are consequences of Coles' and Woolworths' corporate practices and their supermarkets wars. Despite the fanfare of their patriotic initiatives, many of the campaigns seem to be pure rhetoric. A sample of products analysed by the consumer advocacy group, Choice, immediately after Coles and Woolworths announced their new local sourcing policies, found that most of the products sold through the supermarkets' private labels were still foreign (Choice 2012; Dalley 2012b). Moreover, the patriotic campaigns have been proven to be good for business for both supermarkets. Despite criticism of Coles' and Woolworths' practices, both annual corporate reports have shown increases in profits and both have maintained their positions among the world's top 20 Global Powers of Retailing (Deloitte 2014, 12). What is more, while these two supermarkets promise in their advertisements to be responsible retailers, accusations against their 'aggressive' negotiations with suppliers are common in the Australian media (e.g. Mitchell 2014).

SHOPPING IS VOTING: THE SUPERMARKET AS A SITE FOR CITIZEN PARTICIPATION

Since the launch of AFFP and HAG, both Woolworths and Coles have equated shopping at their stores with expressions of patriotism. Campaigns by Woolworths and Coles have suggested that shopping at their stores is not only about getting discounts, but is also an ethical matter and a sign of being a good citizen. Intersections between citizenship and consumerisms have been at the 
centre of discussions related to neoliberal culture and are usually illustrated through the notion of consumer-citizenship (Banet-Weiser and Lapsansky 2008; Özkan and Foster 2005), a condition in which an individual's role as citizen is exercised through consumption practices. The moralisation of Australian supermarkets provokes a particular form of consumer-citizenship, in which shopping and other consumption-related practices are seen as a form of citizen participation in diverse national causes. This form of consumercitizenship becomes visible in AFFP and HAG when Woolworths and Coles encourage consumers to express their sense of belonging to Australia by shopping at their stores and in this way supporting 'Aussie' farmers, national charities and local communities.

In their campaigns Woolworths and Coles invested the act of shopping with political power and presented their stores as places where consumers could go and 'vote with their dollar'. Traditionally, buying at the 'big-two' is considered an opportunity to take advantage of price discounts and not much else. However, the campaigns AFFP and HAG aimed to change this situation. For example, Woolworths' managing director said that they wanted 'shoppers to know that when they buy their fresh food with us they can feel proud that they are supporting a great Australian company as well as Australian farmers and suppliers' (Woolworths 2012d). Coles took a more didactic approach, and the television commercial for HAG showed Curtis Stone explaining: 'so when you're shopping at Coles, guess what? You're helping Australia Grow'. These statements are not only promotional, since they instruct consumers in how to be good citizens, they are also educational and a good example of how marketing is used to influence the behaviour of populations in neoliberal culture (Moor 2011).

Food is one of the areas in which ethical consumerism has rapidly flourished (e.g. Grazia and Uusitalo 2014; Johnston, Szabo and Rodney 2011), and one of the strategies used to invest shopping with ethical significance has been the attribution of moral agency to food commodities. Apart from applying the word 'Aussie' to their foods, both Woolworths and Coles have deployed what cultural geographers call 'geographical knowledges': narratives attached to food products in order to 're-enchant' and differentiate them 'from the devalued functionality and homogeneity of standardised products, tastes and places' (Cook and Crang 1996, 132). In the context of Australian supermarkets, these narratives not only re-enchant food products, but re-nationalise them by attributing them a nationality. The most visible of these narratives has to do with the use of country-of-origin labels. As part of the moralisation of supermarkets, the 'Australian Made' logo has become pervasive, and variations signalling not only the place of origin but of ownership, such as 'Australian Made and Owned', 
have been implemented. Coles has also created labels specifying the state-oforigin of foods using labels such as 'Proudly vic,'Proudly NSW', Proudly QLD' and so on. These movements from country-of-origin to country-of-ownership and state-of-origin suggest that in many cases foods are not valued for their faraway origins. Quite the opposite: the food's moral value has to do with its proximity to the supermarket, or as Woolworths deems it, food is valuable when it comes 'from our very our own backyard' (Woolworths 2012b).

The supposed agency of 'Aussie' food as presented in the campaigns is its power to improve the working conditions of farmers. In order to engage shoppers in this cause, Woolworths and Coles have implemented various narratives. Coles has brought Australian farmers to the supermarket, putting their images on displays that engage directly with shoppers. Contrary to the expectations of many human geographers, the testimonials given by farmers have nothing to do with the industrial exploitation to which they are subjected or with the difficulties of rural life (i.e. Cook 2006; Cook, Crang and Thorpe 1998). Instead, in these displays Australian farmers describe the places where foods are grown: 'The Goulburn Valley region, with cool nights and warm days provides the ideal growing conditions for our apples and pears'; and explain how proud they are of working for the supermarket: 'Chris Fairless, proudly growing pears in viC for Coles for over 9 years.

Another strategy for re-nationalising food has to do with the use of geo-locative media including cartography and QR codes. At both supermarkets, maps of Australia specify the states, regions and towns where fruits and vegetables are grown. These maps are complemented by pictures of landscapes and testimonials from farmers that show the everyday life surrounding food production. More recently, Woolworths and Coles have implemented QR codes that shoppers can scan with their smart-phones to discover information relating to the food they are buying. After scanning the QR code on Woolworths' carrots, for example, shoppers are connected to Anthony Plum, who 'even as a child... knew he wanted to become a vegetable grower' and has been supplying carrots to Woolworths since the mid-1980s (Woolworths 2013d). The information provided by maps, landscapes and QR codes construct romanticised images of agricultural work, rural life and regional Australia that have been useful to sanitise the brand image of supermarkets.

In addition to the campaign highlighting the ways in which Coles and Woolworths are helping Aussie farmers, other national causes are also on display at the supermarkets' stores. The patriotic participation of consumers in these initiatives is always mediated, in one way or another, through consumer-related 


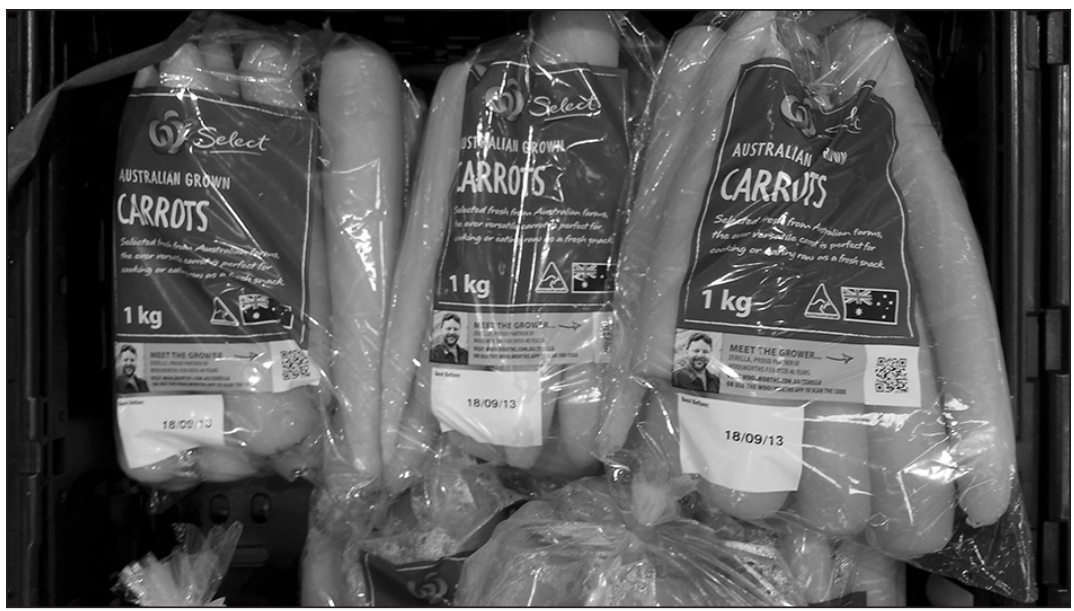

Figure 3. QR codes on Woolworths' carrots

practices. In some cases shoppers are instructed to buy particular foods and other products in order to support organisations and charities. Some of these food commodities have been at the centre of debates raised by the supermarket wars. The most notorious is perhaps Coles' one dollar loaf of bread, a product that has been blamed for its negative impact on local bread brands and small bakeries. On Australia Day 2013, however, the criticised home-brand bread was 'moralised' by Coles announcing that it would donate 5 cents of every loaf sold to Red Kite, the organisation helping people with cancer. Other products that mediate citizen participation in national causes often have souvenir characteristics. Examples of this include badges sold at the check-outs of both supermarkets during April, aimed at raising funds for the Anzac Appeal; the yellow flowers sold at Coles in order to collect funds for Daffodil Day; and the Christmas cards that customers of both supermarkets can personalise with drawings and their name to be pasted on the store's windows.

Supermarkets also encourage customers to adopt an entrepreneurial disposition and help to finance their CSR programs as expression of patriotism. Woolworths asks consumers to support its 'Fresh Food Kids Hospital Appeal' by 'dropping some loose change into (our) collection tins at the checkout' or by playing 'the Money Spinner' installed at different stores. Coles invites customers to donate their Flybuys points to support their 'National Charity Support' program. In other campaigns such as Woolworths' 'Earn \& Learn' and Coles' 'Sports for Schools', supermarkets create their own currency and shoppers 
are given points and vouchers at the check-out according to the money they have spent. Participating schools can then exchange points and vouchers for educational and recreational equipment, and these forms of currency equate amounts of money spent to levels of support. To this end, shoppers are cherished for their patriotic behaviour. Coles publishes on community boards the amount of money raised in their campaigns and Woolworths publishes messages saying: 'Thank you! When you support our initiatives ... you're putting your hard-earned dollar where it's needed the most in our community' (Woolworths, 2012a, 122).

Woolworths and Coles attempt to empower consumers by teaching them how to be good citizens at a national and a local level through the principle that being a good citizen is about being a patriotic consumer. This form of consumer-citizenship echoes recent discussion around the way neoliberalism brings together consumerism and ethics. This idea has allowed the (RED) campaign to sell all kind of red products, from iPhones to Coca-Colas, to fight HIV/Aids in Africa (Richey and Ponte 2011), and Starbucks to sell not only coffee, but a 'coffee ethics' by which customers get involved in diverse social causes while having their espressos (Zizek 2009). The moralisation of Australian supermarkets brings a similar ethic that unites consumerism and citizenship so shoppers can be sure that they are contributing to the nation and their local community while pushing the trolley through the aisles. In this way, patriotic consumers can buy at Woolworth or Coles their redemption as good citizens.

\section{CONCLUSION}

This article demonstrates that a distinctive characteristic of the moralisation of the economy in Australia is the conversion of patriotism into a responsibility of producers, an ethical concern of consumers and a property of commodities. It does so, explaining how Woolworths and Coles released the patriotic campaigns, 'Australia's Fresh Food People' and 'Helping Australia Grow', in order to fight criticism of their irresponsible corporate practices. In these campaigns the supermarkets assume the role of national institutions, marking a series of national causes as their own responsibility, and transform their stores into platforms for citizen participation in the advancement of these causes through their shopping decisions. Despite the nationalist fanfare of these campaigns, this article indicates that far from being altruistic initiatives, AFFP and HAG are part of complex branding strategies aimed at 'washing' the brand image of both supermarkets and at creating markets centred around nationalism.

These findings about the moralisation of the economy and the rise of super- 
market patriotism in Australia confirm the view that neoliberalism and nationalism are not necessarily two opposed paradigms, but can in fact complement each other (i.e. Harmes 2012). This is not only because neoliberal states are successfully commoditising national culture through heritage protection schemes and nation-branding programs (Aronczyk 2013), but also because corporations have shaped commercialised forms of nationalism in order to advance their economic and political agendas (Volcic and Andrejevic 2011). The case presented exemplifies the interaction between neoliberalism and nationalism in the adoption of a nationalist agenda by corporations characterised by their neoliberal power. This suggests that in the absence of a nation-state able to sustain and progress national causes, corporations - in this case supermarkets - have assumed the responsibility of rescuing and advancing the national cause: guaranteeing fair conditions for workers involved in their supply chain, assisting sectors of population in need and providing platforms where consumers can exercise their rights and duties as citizens. However, as the article has warned, far from developing real solutions to national issues, supermarket patriotism proves neoliberalism's ability to transform critique into promotion, moral values in commodities and civic action into shopping practices.

\section{REFERENCES}

ACCC. 2008. Report of the ACCC inquiry into the competitiveness of retail prices for standard groceries. Canberra: Commonwealth of Australia.

Aronczyk, M. 2013. Branding the Nation: The Global Business of National Identity. London: Oxford University Press.

Australian Made. 2000. Australian Made Research. Retrieved February 10, 2014, from http://pandora.nla.gov.au/pan/22837/20011221-oooo/www.australianmade.com.au/research.htm

Australian Made. 2012. Research Summary 2012. Retrieved March 19, 2014, from http://www.australianmade.com.au/media/35435/2012-Research-summary. pdf

Banet-Weiser, S., and Lapsansky, C. 2008. 'RED is the new black: brand culture, consumer citizenship and political possibility'. International Journal of Communication 2, 1248-1268.

Banet-Weiser, S., \& Mukherjee, R. 2012a. 'Introduction. Commodity Activism in Neoliberal Times.' In Commodity Activism. Cultural resistance in neoliberal 
times. Edited by S. Banet-Weiser \& R. Mukherjee, 1-17. New York: New York University Press.

Banet-Weiser, S., \& Mukherjee, R. (Eds.). 2012b. Commodity Activism. Cultural resistance in neoliberal times. New York: New York University Press.

Boje, D.M., Khan, F. R., \& Dawood, S. 2009. 'Story-Branding by Empire Entrepreneurs: Nike, Child Labour, and Pakistan's Soccer Ball Industry.' Journal of Small Business and Entrepreneurship 22(1):9-24.

Bourke, L. 2014. 'Tony Abbott “pleased” with spc Ardmona's \$7om deal to supply Woolworths with fruit and vegetables.' http://www.abc.net.au/news/2014o3-11/spc-ardmona-signs-7om-deal-with-woolworths/5311496

Choice. 2012. 'Coles and Woolies Australia-first sourcing policies more rhetoric than reality: Choice.' Retrieved March 19, 2014, from http://www.choice. com.au/media-and-news/media-releases/2012-media-releases/coles\%2o and\%20woolies\%2oaustralia-first\%2osourcing\%2opolicies\%2omore\%20 rhetoric\%2othan\%2oreality.aspx

Coles. 2011a. 'Coles' Australia First Sourcing Policy.' Retrieved March 19, 2014, from http://www.coles.com.au/portals/o/content/images/About-Coles/Australia\%2oFirst/Australia\%2oFirst\%2osourcing\%2opolicy\%2obrochure.pdf

Coles. 2012a. 'Coles expands commitment to Aussie-grown frozen vegies.' Retrieved March 6, 2014, from http://www.coles.com.au/about-coles/ news/2012/05/03/coles-expands-commitment-to-aussie-grown-frozenvegies

Coles. 2012b. 'Helping Australia Grow.' Retrieved March 4, 2014, from http://helping-australia-grow.coles.com.au/

Coles. 2012c. 'Media Release: "Helping Australia grow" - Coles launches new website to show customers where fresh fruit and veg comes from.' Retrieved October 10, 2012, from http://helping-australia-grow.coles.com.au/

Coles. 2013. 'Timeline of Helping.' Retrieved March 6, 2014, from http://www.coles. com.au/helping-australia-grow/history-of-helping/timeline

Commonwealth of Australia. 2011. The impacts of supermarket price decisions on the dairy industry. Canberra: Senate Printing Unit. 
Commonwealth of Australia. 2012. Inquiry into Australia's food processing sector. Canberra: Senate Printing Unit.

Cook, I. 2006. 'Geographies of food: following.' Progress in Human Geography $30(5): 655-666$.

Cook, I., and Crang, P. 1996. 'The world on a plate: culinary culture, displacement and geographical knowledge.' Journal of Material Culture 1(2):131-154.

Cook, I., Crang, P., and Thorpe, M. 1998. 'Biographies and geographies: consumer understandings of the origins of foods.' British Food Journal 10o(3):162-167.

Cowie, T. 2011a. 'Stacking the shelves: home brand vs. 'premium', what's the difference? Crikey.' Retrieved from http://www.crikey.com.au/2011/o3/31/stacking-the-shelves-home-brand-v-premium/

Cowie, T. 2011b. 'Stacking the shelves: the home brand backlash, from pollies to rivals. Crikey.' Retrieved from http://www.crikey.com.au/2011/o3/30/stacking-the-shelves-the-home-brand-backlash-from-pollies-to-competitors/

Cowie, T. 2011c. 'Stacking the shelves: the rise and rise of home brand products. Crikey.' Retrieved from http://www.crikey.com.au/2011/03/29/stacking-theshelves-the-rise-and-rise-of-home-brand-products/

Dalley, E. 2012a. 'CHOICE supermarket special: Choice.' Retrieved March 6, 2014, from http://www.choice.com.au/reviews-and-tests/food-and-health/foodand-drink/supermarkets/supermarket-private-labels-and-homebrandproducts/page/aisle-way-robbery.aspx

Dalley, E. 2012b. 'Where are supermarket products sourced? More and more of our groceries are coming from overseas: Choice.' Retrieved March 6, 2014, http://www.choice.com.au/reviews-and-tests/food-and-health/food-anddrink/supermarkets/country-of-origin-of-supermarket-products/page.aspx

Dalley, E., and Sheftalovich, Z. 2012. 'Copyshop: Choice.' Retrieved March 6, 2014, http://www.choice.com.au/reviews-and-tests/food-and-health/food-anddrink/supermarkets/copyshop.aspx

Deloitte. 2014. Global Powers of Retailing. Retail Beyond Begins. London: Deloitte Global Services Limited. 
Fischer, W.C., and Byron, P. 1997. 'Buy Australian made.' Journal of Consumer Policy, 20(1): 89-97.

Fleming, P.J., and Jones, M.T. 2013. The end of corporate social responsibility: crisis \& critique. London: Sage.

Fourcade, M., and Healy, K. 2007. 'Moral Views of Market Society'. Annual Review of Sociology 33 285-311.

Frank, T. 200o. One market under God: extreme capitalism, market populism and the end of economic democracy. New York: Doubleday.

Fyfe, M., and Millar, R. 2012. 'Cheap food comes at a price.' The Age. Retrieved from http://www.theage.com.au/world/cheap-food-comes-at-a-price-201205271zd6a.html\#ixzz2MWlIUbLG

Gabriel, Y., and Lang, T. 2005. 'A brief history of consumer activism.' In R. Harrison, T. Harper, J. 2014. 'Coles, Woolworths raise ire of Kiwis by "systematically” dumping New Zealand produce.' Herald Sun. Retrieved May 8, 2015, from http://www.heraldsun.com.au/business/coles-woolworths-raise-ireof-kiwis-by-systematically-dumping-new-zealand-produce/story-fniodcne-1226819562168

Gabriel, Y., and Lang, T. 2006. The unmanageable consumer: contemporary consumption and its fragmentations. London: Sage.

Grazia, M., and Uusitalo, O. 2014. 'Conflicting values of ethical consumption in diverse worlds - A cultural approach.' Journal of Consumer Culture 14(1):45-65.

Harmes, A. 2012. 'The rise of neoliberal nationalism.' Review of International Political Economy 19(1):59-86.

Hilton, M. 2003. Consumerism in twentieth-century Britain: The search for a historical movement. Cambridge: Cambridge University Press.

Humphery, K. 2010. Excess. Anti-consumerism in the West. United Kingdom: Polity.

Insch, A., and Jackson, E. 2014. 'Consumer understanding and use of country-oforigin in food choice.' British Food Journal 116(1):62-79.

Johnston, J., Szabo, M., and Rodney, A. 2011. ‘Good food, good people: Understand- 
ing the cultural repertoire of ethical eating.' Journal of Consumer Culture 11(3): 293-318.

Littler, J. 2009. Radical Consumption. Shopping for change in a contemporary culture. England: Open University Press.

Littler, J. 2011. 'What's wrong with ethical consumption.' In T. Lewis \& P. Emily (Eds.), Ethical Consumption. A critical introduction. Oxon: Routledge.

Maher, S. 2014. 'Coles' 1ooth birthday gift: 16,00o jobs.' The Australian. March 5. Retrieved from http://www.theaustralian.com.au/business/companies/ coles-10oth-birthday-gift-16ooo-jobs/story-fn91v9q3-1226845903146

Marsland, D. 2001. 'Markets and the social structure of morality' Society 38(2):3338.

Mitchell, S. 2014. 'Supermarkets using "aggressive” price negotiation tactics: suppliers.' Retrieved March 20, 2014, from http://www.brw.com.au/p/business/ supermarkets_using_aggressive_price_jXLuNI8FKYla7ISkTETKaJ

Moor, L. 2011. 'Neoliberal Experiments: Social Marketing and the Governance of Populations.' In Inside Marketing. Edited by D. Zwick and J. Cayla, 299-319. New York: Oxford University Press.

Newholm \& D. Shaw (Eds.) The ethical consumer. Thousand Oaks: Sage.

Özkan, D., \& Foster, R.J. 2005. 'Consumer Citizenship, Nationalism, and Neoliberal Globalization in Turkey: The Advertising Launch of Cola Turka.' Advertising \& Society Review 6(3).

Peattie, K. 2012. 'Researching the unselfish consumer'. In Handbook of Developments in Consumer Behaviour. Edited by V. Wells and G. Foxall, 202-245. Cheltenham: Edward Elgar.

Richards, C., Lawrence, G., Loong, M., and Burch, D. 2012.'A toothless chihuahua? The Australian Competition and Consumer Commission, neoliberalism and supermarket power in Australia.' Rural Society 21(3):250-263.

Richey, L.A., \& Ponte, S. 2011. Brand aid. Shopping well to save the world. Minneapolis: University of Minnesota Press. 
Roy Morgan. 2013. 'Australian-made all the way' Retrieved February 10, 2014, from http://www.roymorgan.com/findings/australian-made-all-theway-201305060449

Roy Morgan. 2014. 'Market share narrows between Coles and Woolworths, while ALDI makes important gains.' Retrieved January 8, 2015, from http://www. roymorgan.com/findings/5427-market-share-narrows-between-coles-woolworths-while-aldi-makes-gains-201402120013

Scherer, A.G., and Palazzo, G. 2011. 'The New Political Role of Business in a Globalized World: A Review of a New Perspective on CsR and its Implications for the Firm, Governance, and Democracy.' Journal of Management Studies 48(4): 899-931.

Seth, A., and Randall, G. 2011. The Grocers. The rise and rise of the supermarket chains (Third Edition ed.). London: Kogan Page.

Shamir, R. 2005. 'Mind the Gap: The Commodification of Corporate Social Responsibility.' Symbolic Interaction 28(2): 229-253.

Shamir, R. 2008a. 'The age of responsibilization: on market embedded morality' Economy and Society 37(1):1-19.

Shamir, R. 2008b. 'Corporate Social Responsibility: Towards a New-Market-Embedded Morality?' Theoretical Inquiries in Law 9(2):371-394.

Stehr, N. 2008. 'The Moralisation of the Markets in Europe.' Society 45(1): 62-67.

Stehr, N., and Adolf, M. 2010. 'Consumption between Market and Morals: A Sociocultural Consideration of Moralized Markets.' European Journal of Social Theory $13(2): 213-228$.

Tesco. 2013. 'What matters now: using our scale for good.' Tesco and Society Report 2013. United Kingdom.

Trudel, R., and Cotte, J. 2009. 'Does it pay to be good?' MIT Sloan Review 50(2):60-68.

Trudel, R., and Gote, J. 2008. 'Does being ethical pay?' The Wall Street Journal. October 15 
Volcic, Z., \& Andrejevic, M. 2011. 'Nation Branding in the Era of Commercial Nationalism. International Journal of Communication 5, 598-618.

Williams, J., Memery, J., Megicks, P., and Morrison, M. 2010. 'Ethics and social responsibility in Australian grocery shopping.' International Journal of Retail \& Distribution Management 38(4):297-316.

Woolworths. (2012a, December). ' 6 ways we're helping give back to the community' Fresh Magazine.

Woolworths. 2012b. 'Australia’s Fresh Food People.' Retrieved March 6, 2014 from www.australiasfreshfoodpeople.com.au/

Woolworths. 2012c. 'Fresh Food Rescue.' Retrieved March 19, 2014, from http:// www.woolworths.com.au/wps/wcm/connect/website/woolworths/ about+us/community/ o5other-projects/fresh+food+rescue

Woolworths. 2012d. 'Woolworths is Australia's Fresh Food People: Woolworths.' http://www.woolworthslimited.com.au/page/The_Newsroom/Press_Releases/Archives/2012/Woolworths_is_Australias_Fresh_Food_People/

Woolworths. 2013a. Did you know? Retrieved March 6, 2014, from http://www. woolworthsfacts.com.au/fast-facts.php

Woolworths. 2013b. Woolworths launches Local Food Sourcing Strategy. http:// www.woolworths.com.au/wps/wcm/connect/website/woolworths/ about+us/woolworths-news/woolworths+launches+local+food+sourcing +strategy

Woolworths. 2013c. Woolworths to invest a further \$3 million to source all deciduous canned fruit from Australia. Retrieved March 6, 2014, from http://www. woolworths.com.au/wps/wcm/connect/website/woolworths/about+us/ woolworths-news/woolworths+to+invest $+\mathrm{a}+$ further $+3+$ million+to+sourc e+all+deciduous+canned+fruit+from+australia

Woolworths. 2013d. Zerella Fresh. Retrieved March 6, 2014, from http://www. woolworths.com.au/wps/wcm/connect/website/woolworths/freshfoodideas/meetthegrowers/growers/zerella?presentationtemplate $=$ mobilemtg

Zizek, S. 2009. First as tragedy, then as farce. London: Verso. 